\title{
De organisatie van informatie van de onderneming: een normatief kader?
}

Hans Strikwerda

SAMENVATTING In weerwil van het gegeven dat we in een informational economy leven wordt voor de vraag over welke informatie het bestuur van een onderneming of instelling moet beschikken om in-control te zijn en zich overigens van zijn verantwoordelijkheden te kunnen kwijten, veelal nog uitgegaan van opvattingen over informatievoorziening die gebaseerd zijn op bedrijfsmodellen uit de economie van de tweede industriële revolutie. De nieuwe business modellen waar steeds meer ondernemingen mee werken impliceren een andere invulling van command \& control, die vooral ligt in een andere organisatie van de informatie van een onderneming. Dit artikel introduceert op basis van de cybernetische informatietheorie die begrippen en referentiepunten met behulp waarvan de organisatie van informatie, zoals vereist om in een informational society in-control te zijn, bepaald en gerealiseerd kan worden.

RELEVANTIE VOOR DE PRAKTIJK In het besturen van een onderneming wordt de organisatie van informatie belangrijker dan de structuur van de interne organisatie. Het gaat hierbij dan wel om een ander begrip van informatie dan verondersteld in de AO/IC en in de ICT. het economisch proces niet alleen een beschrijvende rol (de waarde van een goed bijvoorbeeld) of een signaalfunctie (de marktprijs), informatie is nu zelf ook object van exploitatie, zoals bij ondernemingen als Google en Amazon.com, ofwel het vormt een input in de productiefunctie (Arrow, 1996). Het opbouwen en vasthouden van de concurrentiepositie van de onderneming verschuift naar het innoveren van business modellen waarin elementen een rol spelen als competing on analytics ${ }^{2}$ en competing on information dominance ${ }^{3}$. Daarbij wijzigt de aard van het besturen van de onderneming. De (targets down - plans up) budget-methode (resource allocatie, input-sturing) voor het realiseren van nieuwe strategieën wordt vervangen door het besturen op basis van expliciete en specifieke causale verbanden en de voor creatie en exploitatie van kennis noodzakelijke resource mobilization 4 . Langs die laatste weg, en ook uit de opkomst van de multidimensionale organisatie (Strikwerda 2008) worden de voorspellingen duidelijk van Herbert Simon (1945/1976, p. 307) dat de organisatie van informatie belangrijker zal zijn dan de structuur van de interne organisatie en die van Peter F. Drucker (1988) dat de command $\&$ control organisatie vervangen wordt door op informatie gebaseerde organisaties.

De vraag is in hoeverre de ontwikkelingen in de functiegebieden ${ }^{5}$ als $\mathrm{BIV} / \mathrm{AO}$ en $\mathrm{AO} / \mathrm{IC}$ een antwoord vormen op deze ontwikkelingen. Er is zeker wel sprake van ontwikkelingen in deze gebieden (Kocks, 2003), maar deze geven geen antwoord op de veranderende economische rol van informatie in de economie en in de bedrijfsvoering. Voor een deel heeft dit er mee te maken dat de functies BIV/AO en $\mathrm{AO} / \mathrm{IC}$ als onderdeel worden gezien van de assurance en daarmee vanuit het audit-perspectief worden geformuleerd. Dat is historisch gezien ook begrijpelijk en heeft ook goed gewerkt, maar creëert daarmee ook beperkingen.

Om een aanzet voor een nieuw normatief kader voor de organisatie van de informatie van de onderneming te formuleren wordt in dit artikel als volgt te werk gegaan. In paragraaf 2 wordt vanuit de leer van de business administration (ondernemingsbestuur) een korte historische schets 
gegeven over hoe de organisatie van informatie zich heeft gewijzigd. In paragraaf 3 wordt een aantal aspecten van informatie aangescherpt met behulp van de economische organisatietheorie. In paragraaf 4 wordt het begrip incontrol nader uitgewerkt met behulp van de cybernetica als wetenschappelijke theorie van control. In paragraaf 5 wordt het begrip informatie, eveneens op basis van de cybernetica, nader uitgewerkt. In paragraaf 6 wordt het beoogde normatieve kader voor de organisatie van informatie geformuleerd. In paragraaf 7 tenslotte wordt een aantal conclusies getrokken met betrekking tot de vraag over welke informatie de raad van bestuur dient te beschikken om incontrol te zijn.

\section{Business Administration}

Informatie speelt van oudsher een grote rol in het besturen, maar als gevolg van de sterk dalende kosten van informatie en van communicatie wijzigt de wijze waarop in het besturen gebruik gemaakt wordt van informatie. Dat is het onderwerp van deze paragraaf.

In weerwil van het feit dat het besturen van ondernemingen en instellingen een centrale activiteit is in het maatschappelijk verkeer, zoals bijvoorbeeld uitgedrukt in Chandler's Visible hand (Chandler, 1977), kan er niet van worden gesproken dat er een streng, eenduidig, normatief leerstuk bestaat voor het besturen van een onderneming (Strikwerda, 2002). De publicaties van Barnard, The Functions of the executive (Barnard, 1948), Drucker, The concept of the corporation (Drucker, 1946), Sloan, My years with General Motors (Sloan, 1962/1986), Chandler, Strategy \& structure (Chandler, 1962) hebben de grootste invloed uitgeoefend op bestuurders in de tweede helft van de twintigste eeuw, in het bijzonder op hoe een multidivisionele onderneming te besturen. Daarnaast is nog steeds van grote invloed Fayol's Aministration Industrielle et Générale (Fayol, 1918/1999), voor wat betreft de kerntaken van de bestuurder. Minder bekend is dat Fayol ook al expliciet formuleerde over welke informatie de bestuurder zou moeten beschikken, als onderdeel van contrôle in de vorm van zijn befaamde Tableaux. Ook Du Pont en later Sloan werkten als onderdeel van de invoering van divisies en daarmee decentralisatie, uit over welke (financiële- en niet-financiële) informatie de raad van bestuur met betrekking tot de divisies zou moeten beschikken (Chandler, 1962, p. 44; Stinchcombe, 1990). In deze informatievoorziening was overigens veelal sprake van double control in de zin dat een raad van bestuur naast de door de lijn gerapporteerde informatie, ook het recht had om, doorgaans via stafafdelingen uitgevoerde audits, te beschikken over andere gegevens, veelal met betrekking tot efficiency om daarmee het prestatievermogen van een divisie te beoordelen. Deze double control was nodig om de agency costs in de verhouding tussen raad van bestuur en de leiding van een divisie te reduceren. Essentieel in het klas- sieke leerstuk van business administration was dat de raad van bestuur de verwerving en verwerking van informatie, in het bijzonder die met betrekking tot markten, organiseerde in divisies, en vervolgens afhankelijk was voor hun eigen informatievoorziening van die divisies (Stinchcombe, 1990, p. 22). Dit model wordt in de eenentwintigste eeuw verlaten.

Onder invloed van de opkomst van het vak corporate finance in de jaren tachtig van de twintigste eeuw, in combinatie met (gediversifieerde) portfoliostrategieën, werd in de rapportages van de divisies naar de raad van bestuur de nadruk gelegd op financiële informatie, met als extreme vorm daarvan de als financial holding geleide onderneming (Goold en Campbell, 1987). Dit ging ten koste van niet-financiële informatie-uitwisseling tussen divisies en raad van bestuur. Weliswaar was er daarnaast ook sprake van een groei in het gebruik van niet-financiële informatie maar dit werd vooral geadresseerd via Total Quality Management in de operatie (Wruck en Jensen, 1994) en daarmee binnen de divisies.

Onder invloed van de kapitaalmarkt concentreerden bestuurders zich op die financiële informatie om beschikbare investeringsmiddelen zo efficiënt mogelijk te alloceren naar beschikbare investeringsopties, waarbij divisies zoveel mogelijk self-contained werden georganiseerd opdat deze zouden voldoen aan het concept van corporate finance van de onderneming: een portfolio van op zichzelf staande investeringsprojecten. Hiermee hing samen dat divisies zelf hun informatievoorziening organiseerden. Het proces voor de allocatie van investeringsmiddelen in de multidivisionele onderneming werd normatief beschreven door Bower (1986) in zijn Managing the resource allocation process. De kern daarvan is dat de raad van bestuur algemene doelen en financiële kaders stelt aan de divisies, die dan vervolgens op basis van eigen inzicht over hun markt en ondernemerschap met voorstellen komen hoe die doelen binnen de gestelde kaders te realiseren. Dit wordt het botton-up resource allocatie process genoemd. Dit heeft internationaal brede toepassing gekregen en geldt ook als normatief in de leer van management control (Merchant en Van der Stede, 2003)

In 2005 publiceren Bower en Gilbert From resource allocation to strategy. In dat boek wordt geconstateerd dat Bower's in het bedrijfsleven, maar in essentie geldt het ook de publieke sector, populaire bottom-up resource allocation process niet meer functioneert. Dit proces blijkt niet bestand tegen de toegenomen informatieasymmetrie tussen de operatie en het bestuur, en evenmin tegen het fenomeen van budget gaming. Daarnaast speelt nog een andere factor. Het was Bower gebleken dat veel ondernemingen een nieuwe strategie niet vertaalden in een daarop aangepaste informatievoorziening (reportable dimensions), nieuwe prestatieparameters, het beloningssysteem en andere voor de 
nieuwe strategie noodzakelijke aanpassingen in de organisatie. Met als gevolg dat de implementatie van nieuwe strategieën veelal faalt. Immers informatie dient niet alleen het vastleggen van transacties, rechten, verplichtingen en waarden, of voor het nemen van beslissingen, informatie dient ook de Verhaltungssteuerung in ondernemingen (Wall, 2006, p. 181). Bower en anderen concluderen dat het bottom-up resource allocatie process in de moderne economie faalt (Sull, 2005). Bower formuleert dan wel een revised resource allocation process, maar zelf merkt hij daarbij op dat hij geen antwoord heeft hoe daarin om te gaan met intangible assets (Bower en Gilbert, 2005).

Kaplan en Norton (2004) claimen wel een antwoord te hebben hoe een onderneming te besturen waarin intangible assets een grote rol spelen. Zij werken hun methode uit, mede op basis van praktijkgevallen, in hun publicaties Strategy maps en The execution premium (Kaplan en Norton, 2004; Kaplan en Norton, 2008). Kaplan en Norton's methode gaat uit van (gevalideerde) causale relaties, niet gebaseerd op de productiefunctie zoals impliciet verondersteld in de budgetmethode, maar op de directe en indirecte bedrijfsprocessen zoals nodig om de waardepropositie voor de afnemer te realiseren en langs die weg de beoogde financiële resultaten (Kaplan en Norton, 1996).

In het boek Strategy maps wordt ook de nodige aandacht besteed aan de voor hun methode vereiste informatievoorziening in de totale organisatie. Nadrukkelijk omvat deze informatievoorziening, naast de gebruikelijke historische, interne, financiële informatie, ook toekomstgerichte, externe en niet-financiële informatie, en ongestructureerde informatie. In de methode van Kaplan en Norton ligt besloten dat nadrukkelijk ook op leading parameters wordt gestuurd, niet uitsluitend op lagging parameters. Een ander aspect is dat in de methode van Kaplan en Norton de informatievoorziening niet meer per divisie of werkmaatschappij is georganiseerd, maar concernbreed. Eerder al signaleerden Lash en Urry (1994) dat informatie disembedded wordt georganiseerd uit sociale structuren. Dat wil zeggen dat informatie niet langer 'eigendom' is van een business unit of afdeling, en daar ook fysiek is opgeslagen (veel ondernemingen hebben nog ERP-systemen per divisie!), maar dat informatie, in de vorm van shared service centers voor finance en voor ICT, fysiek buiten divisies en afdelingen is georganiseerd en bij decreet van de raad van bestuur, behoudens enkele veiligheidsrestricties, ook voor iedereen toegankelijk is.

Vermoedelijk is de methode voor het besturen van de onderneming zoals geformuleerd door Kaplan en Norton de op dit moment meest geavanceerde, ook qua uitwerking in de vorm van een normatief kader voor vereiste informatievoorziening. Echter het probleem met de publicaties van Kaplan en Norton is dat deze zich in een tussengebied bevinden van managementboeken waarin een nieuw idee gepopulariseerd wordt, zonder volledige technische uitwerking, en die van leer- of handboeken waarin een methode niet alleen conceptueel wordt geduid, maar ook technisch volledig is uitgewerkt en theoretisch verantwoord. Kaplan en Norton concentreren zich op het operationeel besturen van de onderneming, zij besteden geen of nauwelijks aandacht aan institutionele vereisten, zoals de jaarrekening e.d. Wat wel bijzonder aan hun methode is dat zij nadrukkelijk aandacht besteden aan het planmatig en controlled exploiteren van verschillende typen synergieën, aan de rol van de creatieve kenniswerker, maar ook aan nieuwe ontwikkelingen, zoals dat tegenwoordig het bestuur de lange termijn en de korte termijn niet meer via afzonderlijke afdelingen kan managen, maar dat in toenemende mate dit op één en dezelfde plek moet gebeuren. Daartoe bleek nodig om naast capex en opex een nieuwe uitgavencategorie, stratex, in te voeren (Kaplan en Norton, 2008, pp. 115-117). Een ander bezwaar tegen de publicaties van Kaplan en Norton is dat zij de achtergronden van hun methode weliswaar kennen, maar niet zodanig uitleggen dat de lezer de transformatie van de conventionele methoden en opvattingen naar het nieuwe eenvoudig kan volgen.

Alhoewel er sprake is van ontwikkelingen binnen het vakgebied business administration is daarbinnen (nog) geen normatief (nieuw) kader geformuleerd over welke informatie een raad van bestuur dient te beschikken om incontrol te zijn en zich van zijn verantwoordelijkheid behoorlijk te kunnen kwijten. Die zwakte creëert wel het risico dat dan vanuit andere functies, financial control, ICT, de informatiestroom naar de raad van bestuur wordt bepaald, zonder dat dit goed is afgeleid van de opdracht van de onderneming, de te realiseren strategieën (het economisch model), de belangen van de vennootschap en de vereisten om in-control te zijn. We zien in de praktijk dat het voorkomt, maar het geldt niet voor alle ondernemingen, dat het door de onderneming toegepaste ERP-systeem tot weinig meer in staat is dan het produceren van informatie zoals nodig voor de jaarrekening, en dat is soms dan ook nog gebaseerd op de unit-organisatie. De nu door een aantal ondernemingen (IBM, Albert Heijn, ASML, Nestlé, Heineken) toegepaste multidimensionale informatiesystemen en -rapportages duiden een nieuwe richting voor de organisatie van informatie. Een multidimensionaal informatiesysteem wil zeggen dat de prestaties (omzet, brutowinst) van de onderneming simultaan, zonder menselijke tussenkomst in de vorm van het omzetten van gegevens, over meerdere dimensies (per klant, per marktsegment, per product, per distributiekanaal, per regio, per divisie, per werkmaatschappij, etc.) door het systeem worden gerapporteerd (Strikwerda en Stoelhorst, 2009). Ogenschijnlijk kennen ondernemingen met een multidimensionale organisatie eenzelfde 
structuur van de interne organisatie als die van andere ondernemingen. Echter de werking daarvan (de multidimensionale organisatie), het formuleren van doelen, het omgaan met marktkansen, samenwerking tussen individuen en afdelingen, allocatie van middelen en mensen en het bewaken en corrigeren van prestaties, verloopt heel anders dan in de traditionele organisatie. In de multidimensionale organisatie is er sprake van andere machtsverhoudingen en idem een andere zeggenschap over middelen, wat van invloed is op de waarde en waardecreatie van de onderneming (Hart, 1995).

\section{De economische organisatietheorie en informatie}

In de economische benadering van de interne organisatie staan drie elementen centraal: de partitie en attributie van beslissingsrechten, de methoden voor beloning van individuen en de systemen voor het meten en het beoordelen van de prestaties van individuen en onderdelen van de interne organisatie (Brickley, Smith en Zimmerman, 2001). Hiermee hangt direct samen dat in de economische organisatietheorie (managerial economics, niet te verwarren met bedrijfseconomie) informatie een centrale rol speelt. Vanuit de economische organisatietheorie is een centraal vraagstuk in het ontwerp van de interne organisatie van de onderneming (het zogeheten co-locatiebeginsel) dat diegenen die beslissingen nemen zoveel mogelijk over de daarvoor relevante informatie beschikken als ook de juiste beloningsprikkels hebben om die informatie zo efficiënt mogelijk productief te maken (Brickley, Smith en Zimmerman, 2001, p. 264). Een centrale vraag in de economische organisatietheorie is die naar de informatieverwerkende capaciteit en -snelheid van de organisatie als geheel (Hayek, 1945). In paragraaf 4 zal de achtergrond daarvan worden beschreven. Von Hayek voorzag al dat decentrale informatieverwerking nodig zou worden voor de onderneming, te organiseren door middel van geattribueerde beslissingsrechten. Aanvankelijk werd dit gerealiseerd door middel van de multidivisionele organisatie en de unit-organisatie, zoals in paragraaf 2 beschreven. Naast dat de multidivisionele organisatievorm agency costs induceert tussen de raad van bestuur en het management van de divisies, induceert deze vorm ook horizontale informatieasymmetrie tussen de divisies. Hierbij speelt dan een drietal effecten met betrekking tot het besturen van de onderneming. Het eerste effect is dat het de structuur van de interne organisatie is in combinatie met de capital intensity van in het bijzonder managers (een hoge capital intensity wil zeggen dat managers niet met alternatieve organisatievormen kunnen werken) en in combinatie van de kosten van informatie, die de agenda van de raad van bestuur kan bepalen. Kort, hoe hoger de kosten van informatie, hoe hoger de kans dat de agenda, naar issues, en naar uit welke oplossingen een raad van bestuur kan kiezen, wordt bepaald door de structuur van de interne organisatie, niet door externe ontwikkelingen (Arrow, 1974; Hammond, 1994). Dit kan ten koste gaan van het in-control zijn van de onderneming doordat de onderneming zich niet tijdig aanpast aan de omgeving. Een tweede effect van de door de multidivisionele organisatie geïnduceerde informatieasymmetrie is, dat marktkansen niet gezien of ondergewaardeerd worden. De mens heeft de neiging de interne structuur, van zijn denken, van de onderneming, op de omgeving te projecteren en fenomenen die niet in die structuur passen, te onderdrukken. Een derde effect is dat, omdat voor velen in de organisatie informatieasymmetrie een bron van macht is, dat daardoor teamwork over de divisies heen en daarmee een optimale combinatie van in het bijzonder kennis-activa, niet of niet goed tot stand komt.

De kosten van informatie (en communicatie) dalen al enkele decennia (Jorgenson, 2001). In theorie verminderen daardoor agency costs en het effect van de interne organisatie op de agenda van de onderneming. De dalende kosten van informatie en communicatie in de vorm van e-mail, internet, intranet, social media hebben zeker hun effecten, ook in de interne organisatie van ondernemingen. Die effecten worden geblokkeerd als binnen de onderneming de beschikkingsrechten op informatie, toegang, definities, gebruik, gestructureerd blijven op grond van de structuur van de beslissingsrechten van de multidivisionele organisatie. Het eerder genoemde co-locatiebeginsel spreekt over beschikbaarheid van informatie, niet over eigendom van informatie.

Inmiddels is duidelijk dat, gezien de toenemende complexiteit en dynamiek in de markt en de wijzigende aard van activa (in toenemende mate immaterieel, persoonsgebonden kennis), de kennisverwerkende capaciteit van de multidivisionele organisatie, respectievelijk organisaties met een scheiding tussen ontwikkelings-/ planningsafdelingen en uitvoering, niet toereikend is. Waar Sloan zag dat informatieverwerking wat betreft marktvraag decentraal door divisies gedaan moest worden, dringt zich nu op dat deze informatieverwerking decentraal door individuele medewerkers moet worden gedaan (Alberts en Hayes, 2003). Vandaar ook dat Arrow (1974) stelt dat een organisatie decentraal is wanneer zoveel als mogelijk medewerkers voor zichzelf kunnen bepalen, op basis van hen beschikbare informatie, welke van hun alternatieve initiatieven en beslissingen het meest bijdragen aan het doel respectievelijk de waardeontwikkeling van de onderneming, dit inclusief de externaliteiten van hun beslissingen op andere onderdelen van de organisatie. Vandaar dat de informatie die daarvoor nodig is, het colocatiebeginsel, niet meer binnen de bestaande structuren georganiseerd kan worden. In paragraaf 4 zal worden uitgewerkt dat voor Arrow's vorm van decentrale organisatie ook andere typen informatie nodig zijn opdat de decentrale medewerker verstandige beslissingen neemt. 
Tot de economische organisatietheorie kunnen ook worden gerekend besluitvormings-tactieken (de realoption theory) en ontwerpmethoden (modularity) waarmee informatieverwerving en -verwerking wordt gestructureerd om te kunnen omgaan met onzekerheid (Baldwin en Clark, 2002a; Baldwin en Clark, 2002b). Hiermee hangt dan samen dat in de economische organisatietheorie waarde aan informatie wordt toegekend: naarmate informatie meer onzekerheid reduceert heeft informatie een hogere waarde. Daarmee wordt informatie ook een input in de productiefunctie van de onderneming. Het gaat hierbij niet alleen om gegevens over consumentenpreferenties, in steeds meer ondernemingen worden transactiegegevens (point-of-sales information) ook gebruikt in de productiefunctie om de waardepropositie van de onderneming voor haar afnemers te maximaliseren.

De door Arrow beschreven vorm van decentrale organisaties en het organiseren van een informatieverwerkende capaciteit om met onzekerheid te kunnen omgaan, raakt het vraagstuk van to be in-control.

\section{In-control}

Bij de vraag wanneer een raad van bestuur, respectievelijk een onderneming in-control is wordt veelal gerefereerd aan het COSO ERM model. Dit model concentreert zich hoofdzakelijk op de jaarrekening (Kocks, 2003), terwijl een ander bezwaar is dat het geen aandacht besteedt aan de vereiste van external control ${ }^{6}$ Ook zijn er bezwaren aan te voeren tegen de in COSO ERM gehanteerde definitie van risico; daarmee wordt over het hoofd gezien dat de nieuwe business modellen juist gebaseerd zijn op onzekerheid als bron van winst (Stinchcombe, 1990; Williamson, 2007).

De wetenschappelijke theorie van control is de cybernetica. De cybernetica wordt ook genoemd in de literatuur over $\mathrm{AO} /$ IC, in het bijzonder de regelkring met zijn terugkoppeling (figuur 1). De cybernetica omvat meer dan dat. De cybernetica beschrijft hoe levende systemen, biologische systemen, de mens, sociale systemen, in tegenstelling tot anorganische systemen, georganiseerd zijn, waarbij de functie van die organisatie is om (externe) informatie te verwerken om daarmee energie- en materiestromen zo te sturen dat deze levende systemen in leven blijven, ook onder veranderende omstandigheden. Daarmee is het cybernetische begrip control wezenlijk anders en ruimer van karakter dan het begrip contrôle, contrôle is slechts een onderdeel van het cybernetische begrip control. Voor dit cybernetische begrip control bestaat geen adequate Nederlandse vertaling.?

Control is geprogrammeerd, waarbij het programma zelf ook een vorm van informatie is (Beniger, 1986). De aard van het programma is een conditional statement: IF <boolean expression $^{8}>$ THEN < action $1>$ ELSE <action $2>$, respectievelijk een programma is uit een zeer groot aantal van dergelijke uitdrukkingen opgebouwd.

De programmering van control wordt in vier verschillende niveaus onderscheiden:

- op het moleculaire niveau (DNA, het zenuwstelsel);

- het culturele niveau (culturele programmering door gewoontes, tradities, onderwijs, imitatie, instituties);

- op het niveau van organisatie (handelsgebruiken, handelstechnieken, conventies, routines (Cyert en March, 1992/1963; Nelson en Winter, 1982), bureaucratische organisatie (profit

\section{Figuur 1 De organisatie als programmering van control (voor de niveaus 1 en 2 van control). Gebaseerd op Juran}

(1995) 'E' staat voor extern

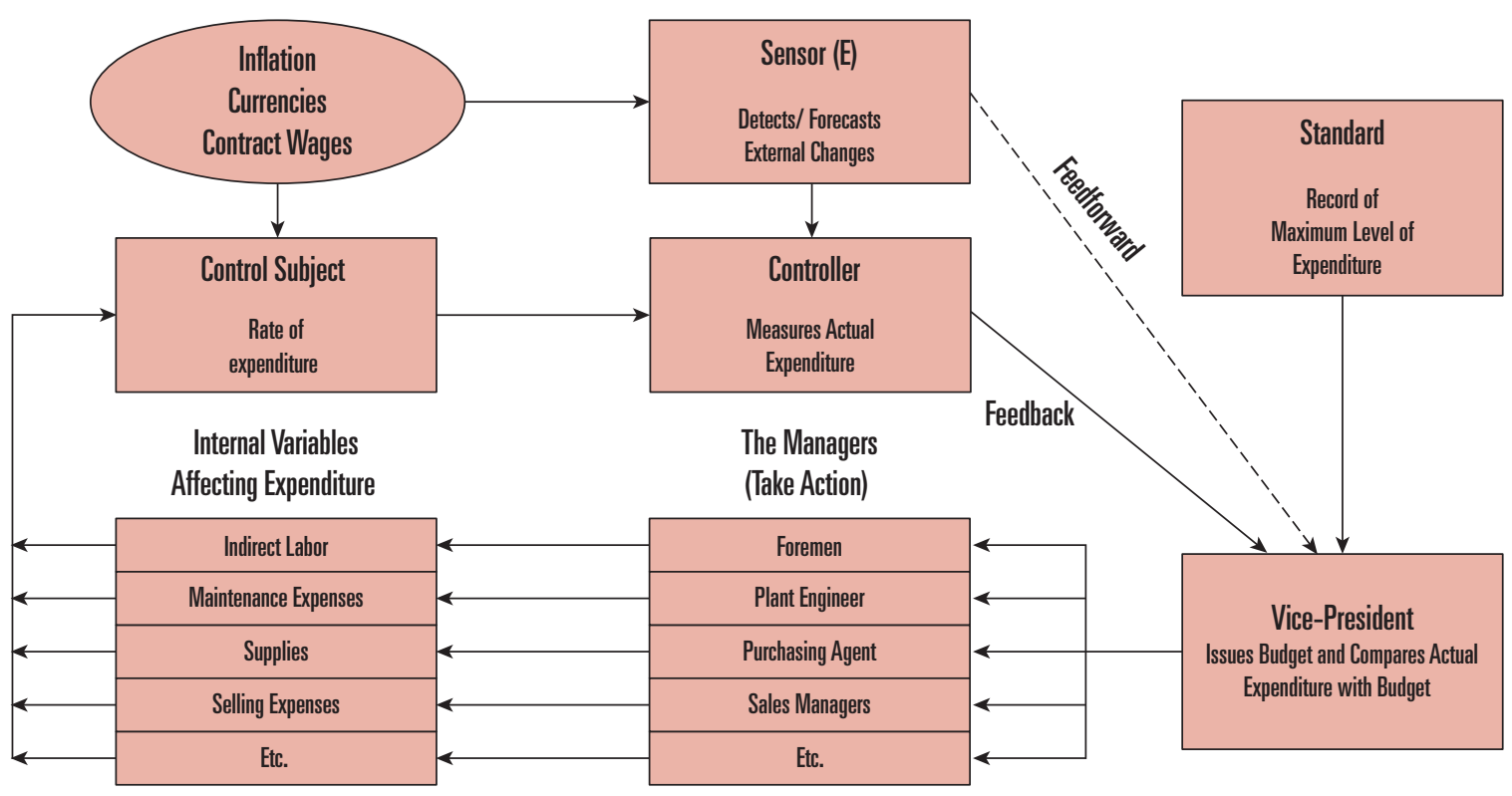


centers, cost centers (Brickley, Smith en Zimmerman, 2001, p. 433), professionele programmering); en

- op het niveau van technologie (computer programma's). Deze vier niveaus van programmering van control impliceren dat de control van een onderneming niet uitsluitend geprogrammeerd is in bijvoorbeeld het management control systeem, of in de $\mathrm{AO} / \mathrm{IC}$, of deels ook in de cultuur, maar besloten ligt (dient te zijn) in de totale organisatie van de onderneming (figuur 1) en daarnaast evenzeer besloten ligt in de institutionele context waarin een onderneming opereert.

Niveau 1 (oog-hand coördinatie van de ambachtsman) en niveau 2 van de programmering van control (door ervaring getrainde werknemer) uit zich in tacit knowledge die van groot belang is voor informatieverwerking (Arrow, 1996; Stinchcombe, 1990), maar niet altijd goed beïnvloedbaar is door de organisatie van de werkgever.

In de cybernetische control om te overleven worden drie niveaus van control onderscheiden (Beniger, 1986). Het eerste niveau is dat van existence or being, dit is de opgave van een levend systeem (een sociaal-economisch systeem zoals een onderneming) om zich zelf in stand te houden, te doen functioneren, ook zonder dat er sprake is van externe veranderingen, om een stijging van de entropie te voorkomen (dat het systeem desintegreert in chaos). Dit herkennen we in de klassieke $\mathrm{AO} / \mathrm{IC}$; zonder een deugdelijke vastlegging van de transacties van de onderneming, de rechten en plichten, de waarden, zonder bescherming van de waarden van de onderneming, zonder borging van routines en competenties, zonder de vereiste externe verantwoording, kan een onderneming niet in stand blijven, zij desintegreert (toename van entropie).

Het tweede niveau van control is experience or behavior, dit is de opgave om de processen die in een organisatie dienen om een gegeven doel te realiseren (daarvoor de nodige informatie, energie en materiaal te verwerven en te verwerken) aan te passen aan variaties en veranderingen in de externe organisatie. Dit is het vermogen om veranderingen in de omgeving te kunnen beantwoorden, in de vorm van capaciteitsflexibiliteit en type-flexibiliteit, zonder dat daarvoor een wijziging in het controlprogramma van de onderneming (het business model, de interne organisatie) nodig is (figuur 1). We herkennen dit in de praktijk in de vorm van flexibiliteitstrategieën, en in de vorm van rolling forecasts, demand management, modulaire opbouw van producten en diensten, e.d. Op dit niveau merkt Simons (2005) op dat er ondernemingen zijn die de fout maken om in-control na te streven door tight control op hun front line workers. Het effect daarvan is dat deze niet experimenteren met nieuwe (operationele) vragen uit de markt, waardoor de adaptability van de onderneming teniet wordt gedaan, en dus de onderneming out-of-control raakt.
Het derde niveau van de cybernetische control is evolution or becoming, dit is de opgave om als gevolg van (meer ingrijpende externe veranderingen) niet-succesvolle of irrelevant geworden doelen en de daarbij behorende processen (business model, interne organisatie) te herprogrammeren, onder behoud van die onderdelen die wel succesvol zijn. We herkennen dit in bijvoorbeeld de transformatie van IBM naar een multidimensionale organisatie, de transformatie van het business model van Albert Heijn (Strikwerda, 2008), de drastische wijziging van het model bij Procter \& Gamble, de explosie van nieuwe business modellen zoals bij Google en Apple (Osterwalder, 2004). Dit niveau van control wordt ook wel aangeduid met business transformation. Het cybernetische begrip control en vooral ook het doel daarvan, overleven in een veranderende omgeving, leidt tot een strenger criterium voor in-control dan geformuleerd in het COSO-ERM raamwerk. De in COSO-ERM genoemde criteria, '... the board of directors and management have reasonable assurance that ( 1 ) they understand the extent to which the entity's operations objectives are being achieved, strategic and operational; (2) published financial statements are being prepared reliably; (3) applicable laws and regulations are being complied with,' zijn weliswaar noodzakelijk om in-control te zijn, maar niet voldoende. In-control zijn wil zeggen dat de onderneming het vermogen heeft zich adequaat, tijdig en efficiënt aan te passen aan veranderende omstandigheden in haar markten. Hiervoor geldt het criterium van Ashby's Law of Requisite Variety (Ashby, 1956): om in-control te zijn moet de variëteit van mogelijke acties van de onderneming hoger zijn dan de variëteit van mogelijke acties van afnemers, concurrenten en toeleveranciers van de onderneming. Omdat door het beter geïnformeerd zijn (via Internet, de media) en een hogere mobiliteit een deel van de consumenten meerdere preferentiesets hanteren, heeft dit een aantal retailers, maar ook uitgevers van tijdschriften, gedwongen tot een meer complex aanbod, met navenant complexe organisatie, om hun share of wallet bij dergelijke afnemers te maximaliseren. Afhankelijk van de aard van de veranderingen in de omgeving van de onderneming vereist in-control zijn ook dat de onderneming het vermogen heeft zich zelf te transformeren (zonder dwang van buiten af), indien externe wijzigingen (markten, technologie, concurrenten, wetgeving, consumentenpreferenties) dat vergen (Donaldson, 1994). $\mathrm{Nu}$ zou gesteld kunnen worden dat de in COSO-ERM geformuleerde criteria voor in-control deze cybernetische criteria voor in control niet uitsluiten als gevolg van de algemene, niet concrete wijze van formulering van toetsingscriteria in dit audit framework. Maar daarmee heeft COSO-ERM niet de kracht a priori aan een concrete situatie specifieke eisen te stellen, zonder dat eerst een concreet toetsingskader wordt geformuleerd. Omdat COSO-ERM niet aansluit bij de economische organisatieliteratuur, niet 
bij die over corporate finance, noch bij andere empirischwetenschappelijke ontwikkelingen, is het maar de vraag of COSO-ERM in concrete situaties kan leiden tot een adequaat concreet toetsingskader.

Wil een onderneming in-control zijn volgens de criteria zoals die voortvloeien uit de cybernetica, dan stelt dat specifieke eisen aan de organisatie van de informatie, niet alleen de pragmatische informatie zoals verondersteld in de $\mathrm{AO} / \mathrm{IC}$, maar ook aan andere typen informatie.

\section{Wat is informatie?}

In de voorgaande paragrafen is op verschillende plaatsen de term 'informatie' gebruikt zonder deze te definiëren; de term is gebruikt in twee verschillende betekenissen, management informatie en het programma van control als vorm van informatie. Met een toenemend belang van informatie in het besturen van ondernemingen en instellingen is het noodzakelijk nauwkeuriger dan in het dagelijks verkeer gangbaar is, om te definiëren wat onder informatie wordt verstaan.

Er bestaan verschillende definities van informatie. Veelal wordt hiervoor gerefereerd an de communicatietheorie van Shannon en Weaver (Shannon, 1948). Informatie zou dan gaan om een bericht van een zender aan een ontvanger als gevolg waarvan de keuzemogelijkheden van de ontvanger uit een bekend eindig aantal acties gereduceerd worden. Echter deze wiskundige theorie van informatie is zo nauw gebonden aan technische systemen (met vaste codificatie en vaste context) dat deze voor sociale systemen wordt afgewezen (Luhmann, 1984), alhoewel de vaste codificatie en vaste context nu juist wel spelen binnen de AO/IC.

\subsection{Doel-informatie}

In de cybernetica worden meerdere typen informatie onderscheiden (Beniger, 1986; Garfinkel, 2008; Van Peursen, Bertels en Nauta 1968). Het eerste type informatie is doelinformatie. Bij ondernemingen treffen we dit bijvoorbeeld aan in de geformuleerde missie. De formulering van een missie van een onderneming of instelling dient aan specifieke eisen te voldoen (Bart, 1999), in de praktijk worden veel fouten gemaakt met de formulering van de missie. Vaak zien we dat communicatieadviseurs er een op de markt van de onderneming gerichte uiting van maken, terwijl de missie van een onderneming in de eerste plaats het bestuur en de medewerkers geldt: 'waartoe is dit bedrijf op aarde'.

Tot de doel-informatie zou ook gerekend kunnen worden de objective function van de onderneming zoals deze onderdeel uitmaakt van het performance management systeem (Jensen en Meckling, 1999; Kaplan en Atkinson, 1989, p. 68). De objective function beschrijft wat de onderneming maximaliseert (bijvoorbeeld winst), wat de onderneming minimaliseert (bijvoorbeeld uitstoot van schadelijke stoffen) en onder welke constraints (bijvoorbeeld een milieuvergun- ning) een en ander gerealiseerd dient te worden. Een eendimensionale objective function (met bijvoorbeeld een monotoon stijgende relatie tussen marktaandeel en winst) blijkt niet te bestaan, er is steeds sprake van niet-lineaire relaties. Daarnaast heeft het maximaliseren van de eendimensionale aandeelhouderswaarde geleerd dat dit tot spreadsheet management leidt en onevenwichtigheid in het functioneren van de onderneming.

Meer in het algemeen geldt dat het te formuleren doel van een onderneming steeds multidimensionaal moet zijn (Drucker, 1958) en complex is (Simon, 1964), ook omdat persoonlijke motieven van medewerkers en ondernemingsdoelen met elkaar verward kunnen raken. Een objective function staat niet op hetzelfde niveau als de missie als vorm van doel-informatie, maar maakt onderdeel uit van het niveau van de strategische keuzes (figuur 2) en dient ingebed te zijn in de context gevormd door de missie en de waardenhiërarchie. Daarmee wordt ook voorkomen dat gekwantificeerde doelen verabsoluteerd worden en pervers worden gebruikt; gekwantificeerde doelen zijn steeds ondergeschikt aan de missie en de waardenhiërarchie van de onderneming.

\subsection{Axiologische informatie}

Het tweede type informatie dat in de cybernetische controltheorie wordt onderscheiden is motiverings- of axiologische informatie. Hierin wordt uitgedrukt welke hiërarchie van waarden een onderneming hanteert in het maken van afwegingen. We zien de laatste jaren een verschuiving van management by objectives naar management by values (Dolan en García Sánchez, 2000). Dit is een tactiek om met de toenemende complexiteit van informatie om te gaan en om met de huidige information overload om te gaan.

Net als bij het formuleren van een missie worden er door ondernemingen en instellingen veel fouten gemaakt bij het formuleren van waarden. Veelal worden verschillende typen waarden verward, er wordt geen hiërarchie aangegeven of men beperkt zich tot operationele waarden (Strikwerda, 2009). Twee punten zijn van belang. Het eerste is dat de waarden van een onderneming of instelling in een hiërarchie geformuleerd dienen te zijn (Cha en Edmondson, 2006). Immers er moeten voortdurend afwegingen worden gemaakt en dan is een hiërarchie van waarden effectief. Het tweede is dat de geformuleerde hiërarchie van waarden ook geld-als-waarde, aandeelhouderswaarde of de going concern-waarde van de onderneming of instelling dient te omvatten. Een klassiek voorbeeld van een waardenhiërarchie die aan deze twee eisen voldoet is Our Credo van de Amerikaanse onderneming Johnson \& Johnson (Collins en Porras, 1994, p. 59). Longitudinaal onderzoek naar de werking van Johnson \& Johnson's Our Credo heeft uitgewezen dat deze een significante rol heeft gespeeld, juist in tijden van crisis, om in-control te blijven. 


\subsection{Externe informatie}

De derde vorm van informatie die in de cybernetische control-theorie wordt onderscheiden is externe informatie. Deze externe informatie bestaat uit twee subcategorieën, materiële informatie en eidetische informatie. Materiële informatie omvat de objectieve feiten met betrekking tot de externe situatie van de onderneming of instelling, marktaandeel, aantal concurrenten, nieuwe concurrenten, aantal afnemers, marktprijzen, technologische ontwikkelingen, sociale ontwikkelingen, wetgeving, e.d. Eidetische informatie bestaat uit de interpretatie van de materiële informatie in het licht van de geformuleerde missie van de onderneming en de geformuleerde waardenhiërarchie (zij het dat de hierna te bespreken effectinformatie hierin ook een rol speelt).

Het genereren van eidetische informatie, wat is de betekenis van externe ontwikkelingen voor de belangen, de strategie en operatie van de onderneming, gebeurt op meerdere niveaus en plaatsen in de organisatie: op het niveau van het bestuur, stafafdelingen, operatie, productmanagement, productontwikkeling, marketing, HRM, etc. Daarnaast genereren ook active shareholders eidetische informatie voor de onderneming. De structuur van de organisatie, het performance management systeem, het beloningssysteem, de allocatie van resources (Burgelman, 2002), alle beïnvloeden de kwaliteit van de eidetische informatie. Eidetische informatie beschrijft welke nieuwe kansen er zijn voor de onderneming, welke nieuwe onzekerheden ontstaan, welke van de aannames en constraints onder de bestaande strategie, respectievelijk het business model niet meer opgaan en welke aanpassingen en transformaties de onderneming zal moeten inzetten om te overleven.

De praktijk leert dat met betrekking tot het verwerven van materiële informatie, in weerwil van de dalende kosten van informatie en de vereenvoudigde toegang tot externe informatie, vooral een aantal psychologische problemen speelt, zoals bijvoorbeeld bounded awareness ${ }^{9}$ en het availability heuristic ${ }^{10}$ (Bazerman en Moore, 2009; Pfeffer en Sutton, 2006). Het genereren van eidetische informatie is eveneens onderworpen aan allerlei psychologische problemen, dominant $\operatorname{logi} c^{11}$, representative heuristic ${ }^{12}$, confirmation $\operatorname{trap}^{13}$, anchoring ${ }^{14}$, etc. (Bazerman en Moore, 2009; Prahalad en Krishnan, 2008; Prahalad en Bettis, 1996). Sutcliffe en Weber (2003) suggereren zelfs dat veel ondernemingen de fout begaan te veel geld uit te geven aan het verwerven van materiële informatie (marktonderzoek, externe adviseurs) maar te weinig aandacht besteden aan het (juist) interpreteren van die informatie. Daarin, en in de eerder genoemde psychologische mechanismen, ligt een belangrijke oorzaak dat ondernemingen out-of-control raken (Jensen, 1993; Malhotra en Bazerman, 2005).

Collins en Porras (1994, p. 187) stellen dat succesvolle ondernemingen bewust informatie zoeken die dwingt tot veran- dering voordat de omgeving de onderneming daartoe dwingt, informatie dus die niet gericht is op assurance, maar op aanpassen, op verandering.

\subsection{Effect-informatie}

Een vierde type informatie dat wordt onderscheiden in de cybernetische control-theorie is effect-informatie. Dit is informatie met betrekking tot causale relaties; 'als x euro meer wordt besteed aan marketing, stijgt het marktaandeel (binnen zoveel tijd) met y procentpunten'. Tot deze effect-informatie behoort ook informatie met betrekking tot feitelijke capaciteiten, efficiency, constraints (technische beperkingen, arbeidsvoorwaarden, vergunningen, fysieke beperkingen) en het time-phased-karakter van causale relaties.

In een sociaal-economisch systeem kunnen nooit alle causale relaties expliciet bekend zijn, laat staan onderwerp van expliciete validatie zijn (bijvoorbeeld door regressieanalyse). Veel gebeurt op basis van routines, tradities, overlevering, emulatie etc. (Simon, 1987). Veel gaat er fout doordat te lang aan oude routines en gewoontes wordt vastgehouden, zowel door managers als door professionals (Pfeffer en Sutton, 2006). Als gevolg van een samenloop van technologische ontwikkelingen, institutionele problemen, demografische ontwikkelingen, geopolitieke ontwikkelingen, ontwikkelingen op de kapitaalmarkt, de zich ontwikkelende multimediale context, staan tal van eens bewezen routines, business modellen, causale relaties, etc. ter discussie als al niet erger. Vandaar ook de eerder beschreven ontwikkeling dat het sturen op input (budgetsturing) vervangen wordt door het sturen op expliciete gevalideerde causale relaties (Kaplan en Norton, 2004) en op statistische analyse van voorhanden data (Davenport, 2006). We zien deze beweging ook gereflecteerd in de definitie van het business model zoals geformuleerd door Osterwalder: 'A business model is a conceptual tool that contains a set of elements and their relationships and allows expressing a company's logic of earning money. It is a description of the value a company offers to one or several segments of customers and the architecture of the firm and its network of partners for creating, marketing and delivering this value and relationship capital, in order to generate profitable and sustainable revenue streams' (Osterwalder, 2004).

In de moderne bedrijfsmodellen is effect-informatie een kwestie van causale complexiteit. Er is sprake van zowel mechanische causaliteit als van structurele causaliteit van gedrag van medewerkers (door de mediale werking van desinformatie; Lash, 2002), maar ook is er sprake van bedrijfsmodellen die nadrukkelijk op onzekerheid zijn gebaseerd en daartoe technieken hanteren als de real option theory (Squire, 2004), modularisatie van producten, diensten, processen en organisatie (Clark en Baldwin, 2002) en open business models respectievelijk open innovation (Chesbrough, 2006). Het lijkt er wel op dat als gevolg van 
de rol van digitale technologie als het ware de mechanische bedrijfsmodellen, met hun hoge mate van determinatie, vervangen worden door wat genoemd zou kunnen worden kwantummechanische bedrijfsmodellen, gebaseerd op onzekerheid. Dit impliceert dat effect-informatie steeds is geformuleerd in meerdere typen relaties, waaronder die in termen van waarschijnlijkheden. Het formuleren van effect-informatie is onderworpen aan de psychologie van bounded rationality en bounded knowledgeability, terwijl ook hier geldt dat er kosten mee gemoeid zijn, zodat er sprake is van een grensnut. In het hanteren van effect-informatie moet daarmee steeds rekening worden gehouden, evenals dat effect-informatie onderwerp van control moet zijn in termen van validatie (March, 2006).

Tot de effect-informatie behoort ook het beloningssysteem van de onderneming. Immers, deze heeft tot functie diegenen die beslissingen nemen van de juiste prikkels te voorzien (co-locatiebeginsel).

\subsection{Pragmatische informatie}

De vijfde vorm van informatie in de cybernetische controltheorie wordt aangeduid met pragmatische informatie of keuze-informatie. Het gaat hier om data bijvoorbeeld in de vorm van een order van een afnemer, maar ook om managementinformatie die tot keuzes of beslissingen moet leiden. Deze pragmatische informatie omvat interne pragmatische informatie (administratieve data en managementinformatie) en externe pragmatische informatie (opdrachten van derden, rechten, verplichtingen, betalingsverkeer e.d.) en is daarmee mede gebaseerd op transactiedata. Naast financiële/accounting informatie dient de pragmatische informatie ook niet-financiële informatie te omvatten, zoals bijvoorbeeld de weersomstandigheden ten tijde van aankoop (Albert Heijn), de samenstelling van de kassabon, tijdstip, plaats, consumentenidentificatie (bonuskaart), etc. Deze vijfde vorm van cybernetische informatie is wat wordt bestreken door de AO/IC respectievelijk BIV/AO. Doordat, ondermeer als gevolg van digitale technologie, steeds meer transacties, zowel met de omgeving als binnen de organisatie, geautomatiseerd worden geregistreerd en vastgelegd, is er sprake van een explosie van de hoeveelheid pragmatische informatie (data). De toenemende hoeveelheid beschikbare data betekent niet automatisch een verhoging van de kwaliteit van de totale informatiehuishouding. Immers wat de beschikbare pragmatische informatie zou kunnen betekenen wordt bepaald door de kwaliteit van het geheel van doel-informatie, axiologische informatie, eidetische informatie en effectinformatie. Nu door onttraditionalisering, door de-institutionalisering, demografische- en technologische ontwikkelingen de kwaliteit van het traditionele niet niet-pragmatische informatiesysteem (cultuur, organisatievormen, stijl van leidinggeven, stijl van besluitvorming) terugloopt, zullen ondernemingen aandacht moeten besteden aan de niet-pragmatische informatievoorziening om in-control te zijn, juist in het geval van de door Arrow beschreven decentrale organisatie.

\section{De betekenis van de cybernetische categorieën van informatie}

Dit artikel begint met de vraag: over welke informatie dient de raad van bestuur te beschikken opdat het zich van zijn verantwoordelijkheid kan kwijten? We kunnen nu begrijpen dat aan deze vraag vooraf dient te gaan de vraag: welk typen informatie dient de raad van bestuur op welke wijze te organiseren in de onderneming als geheel, wil de onderneming in-control zijn?

De verschillende categorieën van informatie zoals beschreven in de cybernetica, bestaan en hebben altijd bestaan binnen ondernemingen en instellingen. Echter, in het bijzonder de doel-informatie, de axiologische informatie en de effect-informatie waren, en zijn vaak nog, impliciet georganiseerd, en/of gefragmenteerd georganiseerd in verschillende functies. HR houdt zich bezig met waarden (maar dan vaak gericht op gedrag), de missie is onderdeel van corporate communicatie, de afdelingen voor strategie en marktonderzoek houden zich bezig met delen van de eidetische informatie, zonder het zo te noemen. Effectinformatie treffen we nog al eens aan binnen de IT-afdeling waar processen worden beschreven, maar evenzeer kan dit het geval zijn binnen de kwaliteitsafdeling, etc. Daarnaast speelt dat van oudsher doel-informatie, axiologische informatie, en deels ook effect-informatie in de hoofden zat van leidinggevenden. De nu verdergaande vereiste van decentralisatie in de informational economy vereist dat deze typen informatie geëxpliciteerd worden in de organisatie en voor iedereen beschikbaar zijn (wat op lager niveau van leidinggevenden eerder werd gerealiseerd door Total Quality Management).

Sommigen zullen zich de vraag stellen hoe verklaard kan worden dat in een periode waarin doel-informatie, axiologische informatie en effect-informatie niet expliciet werd gecommuniceerd in de organisatie, - en als deze al werd gecommuniceerd, dit meer geschiedde in de vorm van instructies -, het economisch toch zo goed is gegaan. Die verklaring bestaat uit twee factoren. De eerste factor is dat tot ongeveer 1990 de vereiste capaciteit voor informatieverwerking redelijk kon worden opgevangen door de traditionele organisatie. De tweede factor is dat besluitvormers hun beslissingen mede laten leiden door de maatschappelijk-institutionele context waarin ze opereren (immers instituties hebben als functie ons gedragsrepertoire in te binden en gedrag voorspelbaar te maken (Picot, Dietl en Franck, 2005; Wall, 2006, pp. 13-17). $\mathrm{Nu}$ deze instituties, staat, kerk, onderwijs, arbeidsverhoudingen, rechtspraak, democratie, verzwakt zijn (Beck en Lau, 2005; Dahrendorf, 2002) vertaalt deze verzwakking 
Figuur 2 Overzicht van de information space zoals nodig om in-control te zijn. Afgeleid van Kaplan en Norton, 2004, p. 33. (MI = management informatie)

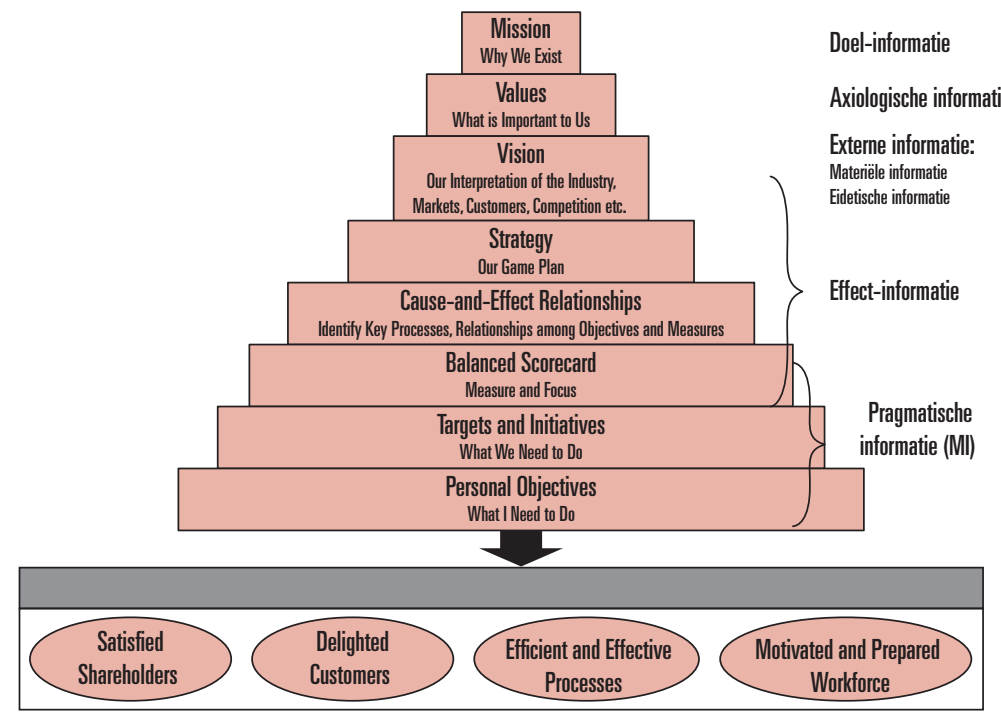

zich in gedrag dat (mede) heeft geleid tot de huidige financiële crisis en dat tot maatschappelijke protesten leidt. Voor de onderneming betekent de verzwakking van de maatschappelijke instituties dat de rol die deze instituties speelden in de interne informatieverwerking binnen de onderneming, nu door de onderneming zelf georganiseerd zal moeten worden. We zien dit in de praktijk veelal nog in intuïtieve vorm, missie-formuleringen, veelal slordig geformuleerde waarden, visies die meer ambitie suggereren in plaats van een interpretatie van externe ontwikkelingen. De intuïtieve reactie van bestuurders op de verzwakkende institutionele context is goed, maar de vertaling van die intuïtie in systemische besluiten, in het bestuurssysteem, moet beter.

Een eerste conclusie uit de voorgaande beschouwing is dat, wil een raad van bestuur in-control zijn, dan getoetst zal moeten worden of de verschillende typen informatie a. adequaat geformuleerd zijn (dit geldt vooral voor de missie en de waardenhiërarchie); b. voldoende bekend zijn bij de belangrijkste spelers in de organisatie; $c$. dat de processen waarmee eidetische informatie wordt gegenereerd gecorrigeerd wordt op de verstorende psychologische factoren, d. dat in ieder geval de meest kritische causale processen expliciet zijn gemaakt, gevalideerd en zo ook worden gehanteerd. Met behulp van technieken als modulaire opbouw van producten en processen moeten variaties uit de omgeving ook verwerkt (kunnen) worden. De pragmatische informatie zal als gedeelde informatie moeten zijn georganiseerd in een concernbreed general ledger, dat voor ieder toegankelijk is (opheffen informatieasymmetrie) en dat het mogelijk maakt dat er simultaan op meerdere dimensies wordt geconsolideerd en gerapporteerd (Strikwerda, 2008). Welke dimensies dat zijn wordt bepaald door a. het business model van de onderneming, b. wat het meest kritisch is in de markt voor het realiseren van de strategie van de onderneming.

Met dit als uitgangspunt kunnen de gebruikelijke $\mathrm{AO} /$ IC-eisen worden gesteld als tijdigheid, foutloosheid, beschikbaarheid/toegankelijkheid e.d. Vaak wordt ook gesteld dat managementinformatie (pragmatische informatie) relevant moet zijn, begrijpelijk en actionable. De cybernetische informatietheorie impliceert dat er in die zin steeds sprake moet zijn van redundantie van informatie, de relevantie van informatie mag niet bepaald worden door het vigerende business model, wat veelal de bestaande praktijk is, maar moet ook signalen bevatten die wijzen op een veroudering van het vigerende business model, op noodzakelijke veranderingen. Informatie die slechts de bestaande situatie bevestigt heeft geen economische waarde.

De begrijpelijkheid van pragmatische informatie wordt bepaald door de kwaliteit van het geheel van doel-informatie, axiologische informatie, eidetische informatie en effect-informatie. Evenzo is het al of niet actionable zijn van pragmatische informatie niet een eigenschap van die informatie, maar wordt bepaald door de aard van het business model en de kwaliteit van de expliciete formulering van het business model.

Figuur 2 geeft een grafische samenvatting van de hiervoor beschreven typen informatie die de information space van de onderneming vormen en daarmee het centrale instrument zijn (als opvolger van structuur) van het besturen van de onderneming.

Figuur 3 Een schematische indeling van de cybernetische informatieruimte

\begin{tabular}{|l|c|c|c|c|c|c|c|c|}
\hline & Missie & $\begin{array}{c}\text { Waarden } \\
\text { hiërarchic }\end{array}$ & $\begin{array}{c}\text { Materiële } \\
\text { informatie }\end{array}$ & $\begin{array}{c}\text { Eidetische } \\
\text { informatie }\end{array}$ & $\begin{array}{c}\text { Objective } \\
\text { function }\end{array}$ & $\begin{array}{c}\text { Effect- } \\
\text { informatie }\end{array}$ & $\begin{array}{c}\text { Pragmati- } \\
\text { sche } \\
\text { informatie }\end{array}$ & $\begin{array}{c}\text { Transactie- } \\
\text { data }\end{array}$ \\
\hline $1^{\text {ste }}$ niveau van control; being & 1,1 & 1,2 & 1,3 & 1,4 & 1,5 & 1,6 & 1,7 & 1,8 \\
\hline $\begin{array}{l}2^{\text {de }} \text { niveau van control; } \\
\text { experience adaptation }\end{array}$ & 2,1 & 2,2 & 2,3 & 2,4 & 2,5 & 2,6 & 2,7 & 2,8 \\
\hline $\begin{array}{l}3^{\text {de }} \text { niveau van control; } \\
\text { becoming transformation }\end{array}$ & 3,1 & 3,2 & 3,3 & 3,4 & 3,5 & 3,6 & 3,7 & 3,8 \\
\hline
\end{tabular}


De combinatie van de verschillende typen informatie (figuur 2) en de drie niveaus van control leiden tot een informatieruimte zoals weergegeven in figuur 3. In figuur 3 zijn ten opzichte van de hiervoor beschreven vijf typen informatie toegevoegd; de objective function, corresponderend met de in de strategie bepaalde doelen en de transactiedata als één van de bronnen voor de pragmatische informatie.

De vraag zou gesteld kunnen worden waar nu verantwoordingsinformatie (jaarrekening, aangifte en andere rapportages) passen in dit schema? Vanuit een cybernetisch perspectief is de functie van verantwoordingsinformatie en andere informatie van de onderneming aan de omgeving, het kunnen beschikken over resources uit die omgeving zoals nodig voor de continuïteit van de onderneming: kapitaal, kennis, energie, materialen, arbeidskracht, afnemers, toeleveranciers, e.d. De functie van deze informatie is ook het bewerkstellingen van een institutionele omgeving die voor de omgeving gunstige of werkbare constraints impliceert. Deze verantwoordingsinformatie is informatie die door de onderneming naar buiten wordt gebracht en door verschillende partijen in de omgeving van de onderneming wordt geïnterpreteerd. In die zin kunnen we onderscheid maken tussen binnenkomende materiële informatie en uitgaande materiële informatie. De uitgaande materiële informatie zal de gebruikelijke gegevens omvatten zoals de jaarrekening, jaarverslag, aangiftes e.d., maar zal ook de missie en de waardenhiërarchie kunnen omvatten. ${ }^{15}$ De eidetische informatie, de interpretatie door leden van de organisatie, is mede van invloed op welke informatie de onderneming of instelling naar buiten zal willen brengen om in-control te zijn. Vandaar dat in figuur 3 de verantwoordingsinformatie bij de categorie materiële informatie als uitgaande materiële informatie wordt gerangschikt.

Gegeven de hiervoor beschreven niveaus van control, de verschillende typen informatie en de functie daarvan, kan een aantal opmerkingen worden gemaakt wat issues zijn in, respectievelijk waaraan de informatie in elk der cellen in figuur 3 dient te voldoen. Dit wordt uitgewerkt in tabel 1. Daaraan vooraf geldt een aantal meer generieke kwaliteitscriteria voor de kwaliteit van informatie. Het Enterprise Risk Management - Integrated Framework van COSO (2004, p. 70) stelt dat de kwaliteit van informatie wordt bepaald door de volgende criteria:

1. Content is appropriate - Is it at the right level of detail?

2. Information is timely - Is it there when required?

3. Information is current - Is it the latest available?

4. Information is accurate - Is the data correct?

5. Information is accessible - Is it easy to obtain by those who need it?
De formulering van deze eisen impliceert dat COSO uitsluitend spreekt over pragmatische informatie en de transactiedata. Maar ook binnen die beperkingen impliceert de cybernetische informatietheorie een aantal specifiekere eisen aan de kwaliteit van pragmatische informatie, respectievelijk transactiedata.

1. Of de inhoud van informatie 'appropriate' is wordt deels bepaald door het gehanteerde business model en de daarin toegepaste causale processen, maar mag daartoe niet beperkt worden. Ogenschijnlijk niet-relevante informatie of niet verwerkbare informatie kan ook een signaal zijn dat veranderingen noodzakelijk zijn. Of informatie van het juiste niveau van detaillering is, is een eis die teruggaat op de traditionele consolidatie en rapportagelijnen en het daarmee samenhangende informatieverlies. Een betere eis is dat transacties zo gedetailleerd mogelijk worden vastgelegd (zoveel mogelijk attributies of dimensies) en dat deze detaillering te allen tijde behouden blijft en toegankelijk blijft. Immers gezien de dalende kosten van informatie is er geen aanleiding om informatie, bijvoorbeeld na een consolidatie, te schrappen. Albert Heijn houdt alle kassabonnen twee jaar vast om te gebruiken voor analyse en business intelligence.

2. Met betrekking tot de eisen dat informatie tijdig en actueel moet zijn kan worden opgemerkt dat steeds meer ondernemingen er in slagen, ook doordat transacties digitaal worden verwerkt en vastgelegd, om transacties real time vast te leggen. Dat betekent, afgezien van een aantal minuten machinetijd voor verwerking, dat verkopen, projecten, etc. bijna real time of in ieder geval dagelijks gevolgd kunnen worden. Kostenallocaties kunnen soms iets meer tijd vergen, maar niet meer dan een week. De tijdige beschikbaarheid van informatie voor managers en medewerkers kan dus gebaseerd worden op het tegenwoordige nagenoeg real time karakter van het vastleggen van transacties, in combinatie met de constitutionele beslissing dat de informatieasymmetrie wordt opgeheven, waardoor medewerkers, productmanagers, planners niet meer afhankelijk zijn van collega's voor rapportages.

4. Dat vastgelegde data correct moet zijn spreekt voor zich, maar het correct zijn van data of informatie is nog niet hetzelfde als het betrouwbaar zijn van data, daarin speelt een sociale component. Data zou als betrouwbaar kunnen worden ervaren op basis van system based trust, maar gezien de ervaringen met IT-systemen is dat niet in alle situaties automatisch het geval. Personen zoeken steeds naar redundantie in informatie in sociale zin: wie heeft, onder welke omstandigheden, met welk motief, deze data in het systeem ingevoerd? Ofwel, data, informatie wordt eerder vertrouwd op basis van experience based trust. Naarmate transacties meer geautomatiseerd worden 
Tabel 1 Waaraan dienen de verschillende typen informatie in de organisatie te voldoen?

\section{Informatie-cel \# Issues, criteria}

1,1 Is de missie vertaald in de objective function? Bijvoorbeeld: een nutsbedrijf streeft betrouwbare energievoorziening na, staat in de objective function dan ook een minimaal te handhaven up-time van het netwerk?

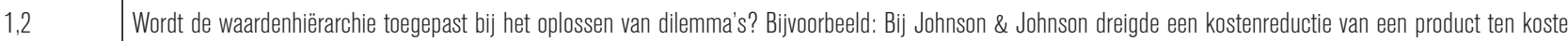
te gaan van de kwaliteit daarvan, Our Credo impliceerde dat de kostenreductie niet werd doorgevoerd.

1,3 Worden gegevens voor transacties en verantwoording, afnemers, toeleveranciers, belastingdienst e.d. zo volledig mogelijk, tijdig en foutloos vastgelegd, toegankelijk gemaakt, uitgewisseld? En wel zo dat consolidatie op meerdere dimensies mogelijk is? (product, afnemer, regio, vestiging, projecten, synergieën, etc.)

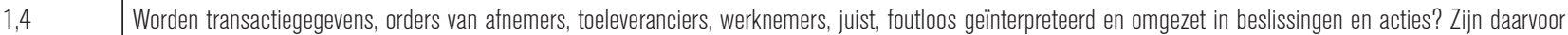
de nodige instructies en programma's opgesteld, gecommuniceerd en getraind?

1,5 $\quad$ Is het de verschillende functionarissen duidelijk wat ze moeten maximaliseren, wat ze moeten minimaliseren, onder welke constraints, beschikken zij over goede rekenmodellen daarvoor, worden rekenmodellen met elkaar gedeeld ter wille van de zelfcoördinatie?

\begin{tabular}{l|l}
1,6 & Zijn de meest kritische processen voor het realiseren van de waardepropositie voor de afnemer beschreven, objectief gevalideerd en gecommuniceerd? Is er een
\end{tabular} gevoeligheidsanalyse opgesteld (risicoanalyse)? Zijn van die processen op onderdelen de leading en lagging input en prestatieparameters bekend en opgenomen in het control process?

1,7 Hebben medewerkers steeds op het juiste moment, op de juiste plaats toegang tot de noodzakelijke informatie die betrouwbaar is om vereiste beslissingen te kunnen nemen en acties uit te voeren?

1,8 Worden alle transacties, externe en interne (urenregistratie, materiaalverbruik, materieelgebruik) zo snel mogelijk geautomatiseerd vastgelegd in één grootboek?

2,1 Worden, als er nieuwe vragen en issues uit de markt komen (afnemers, toeleveranciers, arbeidsmarkt) deze mede vanuit de missie geïnterpreteerd en gewaardeerd?

2,2 $\quad$ Als 2,1

2,3 $\quad$ Is er openheid voor nieuwe vragen uit de markt waar de onderneming iets van zou kunnen leren? Bijvoorbeeld, Simons (2005) beschrijft hoe tight control bij front line workers er toe leidt dat wanneer een klant met een nieuwe vraag binnenkomt, er niet geëxperimenteerd wordt hoe de onderneming daarmee om zou kunnen gaan (adaptation) waardoor uiteindelijk de onderneming out-of-control raakt.

Wordt in de verantwoordingsinformatie er blijk van gegeven dat de onderneming georganiseerd is om met veranderingen in de omgeving om te gaan, respectievelijk wordt de omgeving ter wille van de onderneming beïnvloed?

\begin{tabular}{l|l} 
2,4 Worden de psychologische mechanismen die tot een onjuiste interpretatie van materiële informatie leiden onderkend en via een sociaal systeem (bijvoorbeeld
\end{tabular} interactive control, team bespreking, delen van informatie) zo goed mogelijk gecorrigeerd?

2,5 $\quad$ Wordt de validiteit van de objective function bewaakt? Bijvoorbeeld, in de verschillende fasen van de product life cycle, maar het kan ook de marktontwikkeling gelden, moet doorgaans op verschillende parameters en constraints worden gestuurd.

2,6 Wordt de validiteit van (de meest kritische) causale relaties bewaakt, door beoogde effecten te vergelijken met feitelijke effecten? Worden processen aangepast/ verbeterd waar dit aan de orde is?

2,7 Wordt informatie die afwijkt van bestaande patronen gebruikt om na te gaan of er iets in producten en processen aangepast moet worden, of wordt dit ontkend? Wordt demand management alleen gebruikt om de vraag uit de markt te voorspellen of ook om te analyseren of er sprake is van structurele wijzigingen en trendbreuken?

2,8 $\quad$ Biedt het systeem voor het vastleggen van transactiedata voldoende flexibiliteit om afwijkende vragen van afnemers vast te leggen en te verwerken?

3,1 Is er regelmatig een beschouwing over veranderingen in de omgeving die aanleiding kunnen vormen tot het op een andere wijze (producten, processen) realiseren van de missie?

\begin{tabular}{l|l}
3.2 & Als 3,1
\end{tabular}

3.3 Wordt voldoende breed en diep gekeken naar ontwikkelingen in de omgeving die van betekenis kunnen zijn voor de onderneming en het realiseren van het doel van de onderneming?

3,4 Is er intellectuele ruimte, een psychologisch klimaat, mutual trust, om te exploreren welke meer fundamentele ontwikkelingen mogelijk gaande zijn in de omgeving en wat die zouden kunnen betekenen voor de onderneming?

3,5 Wordt (zie ook 3,6) het in de objective function gehanteerde rekenmodel op validiteit getoetst?

3,6 $\quad$ Wordt het business model op validiteit getoetst, is er sprake van exploratie naar betere, nieuwe business models?

Is er in de verantwoordingsinformatie (jaarverslag) sprake van informatie dat de leiding van de onderneming fundamentele veranderingen (voor)ziet in de omgeving van de onderneming, waarmee de omgeving (stakeholders) van de onderneming ontvankelijk worden gemaakt voor fundamentele transformatie van de onderneming?

3,7 Is de pragmatische informatie zodanig gedefinieerd en vastgelegd dat daarop exploratief nieuwe business models kunnen worden uitgeprobeerd, geëvalueerd en geïmplementeerd?

3,8

Als 3,7 
vastgelegd kan daarvoor in toenemende mate sprake zijn van system based trust, maar dit blijft lastiger voor materiële gegevens met betrekking tot veranderingen in de omgeving, laat staan eidetische informatie. Ook kostenallocatie is een gevoelig onderwerp waaraan veel energie verloren gaat. $\mathrm{Nu}$ ook steeds meer interne activiteiten (urenregistratie naar producten, afnemers) gedetailleerd worden vastgelegd, alsook het beslag op productiemiddelen, kan de allocatie van kosten (naar producten, afnemers, marktsegmenten) steeds nauwkeuriger worden gerealiseerd. Ondernemingen als IBM en ASML lossen dit zo op dat hun corporate afdeling finance/accounting als trusted source geldt voor de kostenallocatie, zodat creative knowledge workers daaraan geen energie verliezen, maar ook managers niet, zij dienen zich te concentreren op te lossen issues met afnemers (Strikwerda, 2008).

5. $\mathrm{Nu}$ concurreren is verschoven van concurrentie op capaciteiten naar concurrentie door innovatie van producten en diensten en innovatie van business models, is het van belang dat creative knowledge workers hun energie kunnen concentreren op toepassing van hun kennis en zich niet hoeven te verliezen in discussies over wat de toestand van een product, de onderneming, etc. is met betrekking tot winst, contributiemarge van een product, e.d. Laat staan dat energie verloren moet gaan over het verkrijgen van informatie. De informatieasymmetrie, die in de traditionele vorm van het werken in teams als dominante factor voor gedrag gold (Marschak en Radner, 1972), is niet langer technisch noodzakelijk en ook niet meer acceptabel.

COSO stelt merkwaardigerwijs niet de expliciete eis dat er vertrouwen moet zijn in informatie. Mogelijk is verondersteld dat de hiervoor genoemde eisen daartoe leiden. Dat is maar de vraag. Vertrouwen in de organisatie wordt door factoren bepaald als (Whitney, 1996):

1. congruentie tussen de missie, de waarden van de onderneming, gedrag van leidinggevenden en medewerkers, contributie en beloning;

2. het vakmanschap en professionaliteit van leidinggevenden en collega's;

3. begrip van de werking van de onderneming en de interne organisatie van de onderneming als sociaaleconomisch systeem,

4. integriteit van leidinggevenden en medewerkers,

5. handelingsalternatieven waarover individuen zelf beschikken (hoe hoger hoe minder behoefte aan vertrouwen; Luhmann, 1968).

Whitney stelt dat vertrouwen in de organisatie ook afhangt van vertrouwen in de pragmatische informatie binnen de organisatie. Vertrouwen in pragmatische informatie als system trust hangt mede af of er een context bestaat, missie, waarden, sociaal systeem, geëxpliceerd business model waartegen en waarbinnen het individu en groepen zelf betekenis kunnen verlenen aan beschikbare data en over data kunnen beschikken. Op grond van het voorgaande illustreert dat eens te meer het belang van goede doel-informatie en idem axiologische- en effectinformatie (punt 3 hierboven). Omgekeerd maakt een dergelijke context het mogelijk dat beslissingen worden genomen op basis van imperfecte pragmatische informatie (wat deze altijd is) wat weer bijdraagt aan zelfvertrouwen. Vanuit dit gegeven en de hiervoor beschreven drie niveaus van control kunnen dan specifiekere eisen aan de informatie worden gesteld. Deze zijn samengevat in tabel 1.

\section{De nieuwe informatievoorziening voor het bestuur}

We zien dus dat als gevolg van de mogelijkheden voor en de noodzaak tot het opheffen van informatieasymmetrie, de raad van bestuur niet meer afhankelijk is van door managers in de organisatie opgestelde rapportages. Verwacht mag worden dat, mede onder druk van de kapitaalmarkt, dit niet-afhankelijk zijn een norm wordt in het maatschappelijk verkeer. Dat wil zeggen, dat het bestuur op elk moment de toestand van de onderneming, prestaties, rechten, verplichtingen, op meerdere dimensies kent, dus niet alleen zoals geformuleerd in de jaarrekening, in relaties tot gestelde doelen en voorziene ontwikkelingen, en daarvoor niet meer afhankelijk is van door personen aan te leveren informatie.

Tegelijk zien we dat het bestuur zich explicieter bezig moet houden met de kwaliteit van de organisatie van het totaal aan typen informatie zoals weergegeven in figuur 2 en in tabel 1 en de daarop gebaseerde processen. Dit vergt meta-informatie die deels door internal audit gegenereerd zal moeten worden, en anderzijds onderwerp zal moeten zijn van in het bijzonder de interactive control (Simons, 1995) in de organisatie.

Doorslaggevend is hoe het bestuur, zichtbaar voor de organisatie, laat zien hoe het welke informatie gebruikt. Als het bestuur heeft gesteld dat key account management centraal staat in de strategie van de onderneming, beoordeelt het bestuur dan ook wekelijks deze dimensie als reportable dimension, compleet met een terugkoppeling of corrective actions naar diegenen die daarvoor verantwoordelijk zijn? Of meer in het algemeen, heeft het bestuur gedefinieerd welke de kritische reportable dimensions zijn voor de strategie van de onderneming, en wordt daarop ook gestuurd? Ook is van belang dat het bestuur zichtbaar voor de organisatie meta-control uitoefent: kloppen aannames nog wel? Daarbij is van belang dat het bestaan van dominant logic als mechanisme dat in-control in de weg kan staan wordt onderkend en op grond van eidetische informatie waar nodig ter discussie wordt gesteld. Daarmee laat het bestuur ook zien dat het zelf actief de agenda van de onderneming bepaalt, en dat deze niet wordt beperkt door bestaande belangen in de interne organisatie. 
Wat we met dit nieuwe antwoord op de vraag: over welke informatie dient het bestuur te beschikken, zien is dat de Romeins-Weberiaanse wijze van besturen wordt vervangen door information based besturen, zoals voorspeld door Drucker (1988). Het Romeinse model hield in dat de totale bestuurstaak werd opgedeeld in territoria die elk afzonderlijk opereerden, het Weberiaanse model impliceerde dat de positie-houder monopolie had op informatie, respectievelijk op de interpretatie daarvan. Onder invloed van internet, gaming, wikinomics, ontstaat er een generatie managers die niet meer positie-georiënteerd zijn, maar contributie-georiënteerd zijn (Beck en Wade, 2006; Himanen 2001). Voor deze generatie is motivatie niet meer gebaseerd op control over resources, maar op hun door anderen erkende contributie aan het gemeenschappelijk doel. Machtsverhoudingen in de interne organisatie kunnen niet meer gebaseerd zijn op informatieasymmetrie, maar verschuift naar die medewerkers die in staat zijn een situatie te doorgronden in termen van wat er moet gebeuren. Command is niet meer een commando van een commander naar een medewerker, maar de interpretatie van de situatie door de medewerker op basis van missie, waarden, doel en causaliteit. Control bestaat niet meer uit gedragsregels of restrictic van gedrag, maar is gebaseerd op transparantie en fast feedback.

Chandler (1962) definieerde ondernemingsbestuur als planning, coördineren en beoordelen, daarin verandert niets, de inhoud en instrumenten worden anders. De primaire zorg van de bestuurder, de motivatie van managers en medewerkers om te ondernemen, blijft de primaire zorg. De grondslag van motivatie verschuift, maar identificatie met het doel, de waarden van de onderneming, blijft centraal staan als wat mensen bindt en motiveert (Simon, 1991). Het creëren en onderhouden van die context is de uitdaging van besturen.

Prof. Dr. J. Strikwerda CMC, Universiteit van Amsterdam,

Faculteit voor Economie en Bedrijfskunde, afdeling Business

Studies, Director van het Nolan Norton Institute te Zeist. De

auteur is enkele anonieme reviewers zeer erkentelijk voor

hun constructieve commentaren op de oorspronkelijk

ingediende tekst.

\section{Noten}

1 Discursieve informatie is technische, wetenschappelijke, financiële informatie, deze is abstract, gevalideerd, en reduceert complexiteit. Desinformatie is informatie als cultuur, bijvoorbeeld YouTube, Twitter, deze heeft logische- noch existentiële betekenis, het is vluchtig en biedt geen ruimte voor reflectie.

2 Dit is het fenomeen dat ondernemingen als bijvoorbeeld Google en Albert Heijn, hun transactiegegevens met klanten systematisch analyseren op patronen, ontwikkelingen en bijzonderheden, om op basis daarvan het aanbod aan afnemers te preciseren en te verbeteren (Davenport, 2006).

3 Dit is het fenomeen in het bedrijfsleven, maar het speelt ook in de militaire wereld, waarin een superieure concurrentiepositie wordt opgebouwd en verdedigd doordat de onderneming over meer kennis over afnemers beschikt dan de concurrent, respectievelijk kennis over afnemers sneller en effectiever kan omzetten in een concurrerend aanbod.

4 Dit is het fenomeen dat in bedrijven waarin creatieve kenniswerkers een grote rol spelen (farmacie, software, professionele dienstverlening) die kenniswerkers, gegeven een goed functionerende infrastructuur voor het meten en vastleggen van prestaties van individuen en teams en een overigens adequate informatievoorziening, grotendeels zelf bepalen waar zij hun kennis en inzichten het beste kunnen inzetten (Doz, 2005) 5 Kocks (2003) spreekt over BIV als een 'vak', dit is onjuist, BIV/AO, AO/IC zijn functies in het systeem van de interne organisatie van de onderneming.

6 Zie over external control o.m. De Kuijper (2009), Fligstein (1990), Kim en Mauborgne (2005) en Pfeffer en Salancik (2003).

7 Van Dale's woordenboek Engels-Nederlands vertaalt control met 'beheersing', in de zin van ergens militaire of politieke macht over uit te oefenen, in de zin van zeggenschap, gezag, dwang, beteugeling. Dat schiet tekort waar het gaat over control in cybernetische zin.

8 Zie hiervoor de Boolean algebra, in het bijzonder de truth-values, een uitdrukking als bijvoorbeeld $x<y$ is waar (truth-value 1) of niet waar (truth-value 0), waardoor deze algebra door binaire computers verwerkt kan worden.

9 Dit is het fenomeen dat mensen zich slechts bewust (willen) zijn van delen van hun omgeving. 10 Dit is het fenomeen dat mensen geneigd zijn zich door informatie te laten leiden die gemakkelijk voorhanden is en niet verder te zoeken. 11 Dit is het fenomeen dat in het bijzonder succesvolle managers zich een aantal vuistregels voor het nemen van beslissingen ontwikkelen, zonder de validiteit daarvan voor nieuwe situaties ter discussie te stellen en als gevolg van het zich onbewustzijn van die regels daardoor de onderneming in problemen kunnen brengen.

12 Dit is het fenomeen dat managers de waarde of kans van slagen van een beslissing laten afhangen van de vraag in hoeverre de inhoud van die beslissing lijkt op beschikbare data in plaats van die waarde of kans objectief te bepalen. 12 Dit is het fenomeen dat in het afwegen van alternatieve beslissingen onbewust die informatie wordt geselecteerd die het alternatief met een intuitieve of emotionele voorkeur bevestigt. 14. Dit is het fenomeen dat een discussie of soms zelfs een berekening, bijvoorbeeld voor een omzet, een rendement, een kostenbesparing, blijtt ronddraaien rond een getal dat vroeg in de discussie ter tafel is gebracht.

15 Zie Holbrook's schema voor extended composite consumer value waarin hij beschrijft dat consumenten in een product of dienst niet alleen een economische waarde zoeken, maar veelal ook sociale waarden, hedonistische waarden en altruistische waarden (ethiek, waarden van de civil society). Zie: Gallarza et al, 2006) 
alberts, D.S. en R.E. Hayes (2003), Power to the edge: command, control in the information age, Washington, DC: CCRP Publication Series.

- Arrow, K.J. (1974), The limits of organization, New York: Norton.

- Arrow, K.J. (1996), The economics of information: An exposition, Empirica, vol. 23, pp. 119-128.

- Ashby, W.R. (1956), An introduction to cybernetics, vol. 1999, London: Chapman \& Hall.

Baldwin, C.Y. en K. Clark (2002a), The fundamental theorem of design economics, Harvard Business School Working Paper No. 02-077, Harvard NOM Working Paper No. 02-12.

Baldwin, C.Y. en K. Clark (2002b), The option value of modularity in design: An example from design rules, Volume 1: The power of modularity, Harvard Business School.

Barnard, C.I. (1948), The functions of the executive, Cambridge, Mass.: Harvard University Press.

Bart, C.K. (1999), Mission statement content and hospital performance in the Canadian notfor-profit health care sector, Health Care Management Review, vol. 24, pp. 18-29.

- Bazerman, M.H. en D.A. Moore (2009), Judgment in managerial decision making, Hoboken, NJ: John Wiley \& Sons.

- Beck, J.C. en M. Wade (2006), The kids are alright: How the gamer generation is changing the workplace, Boston, Mass.: Harvard Business School Press.

- Beck, U. en C. Lau (2005), Second modernity as a research agenda: theoretical and empirical explorations in the 'meta-change' of modern society, The British Journal of Sociology, vol. 56, pp. 525-557.

- Beniger, J.R. (1986), The control revolution: technological and economic origins of the information society, Cambridge, Mass.: Harvard University Press.

- Bleicher, K. (1992), Das Konzept Integriertes Management, Frankfurt: Campus Verlag.

- Bower, J.L. (1986), Managing the resource allocation process, Boston, Mass.: Harvard Business School Press.

Bower, J.L. en C.G. Gilbert (2005), A revised model of the resource allocation process, in: J.L. Bower en C.G. Gilbert (eds.), From resource allocation to strategy, (pp. 439-455), Oxford Oxford University Press.
Brickley, J.A., C.W. Smith en J.L. Zimmerman (2001), Managerial economics and organizational architecture, Boston: McGraw-Hill.

- Burgelman, R.A. (2002), Strategy as vector and the inertia of coevolutionary lock-in, Administrative Science Quarterly, vol. 47, pp. 325-357.

- Cha, S.E. en A.C. Edmondson (2006), When values backfire: Leadership, attribution, and disenchantment in a values-driven organization, The Leadership Quarterly, vol. 17, pp. 57-78.

- Chandler, A.D. (1962), Strategy and structure: Chapters in the history of American enterprise, Cambridge, MA: MIT Press.

- Chandler, A.D. (1977), The visible hand: The managerial revolution in American business, Cambridge, Mass.: The Belknap Press of Harvard University Press.

- Chesbrough, H.W. (2006), Open innovation: The new imperative for creating and profiting from technology, Boston: Harvard Business School Press.

- Clark, K. en C.Y. Baldwin (2002), The fundamental theorem of design economics, Available at SSRN: http://ssrn.com/ abstract $=312419$

— Collins, J.C. en J.I. Porras (1994), Built to last: Successful habits of visionary companies, New York: Harper Business.

- COSO (Committee on Sponsoring Organisations of the Tradway Commission) (2004), Enterprise Risk Management Integrated Framework; zie: www.coso.org.

- Cyert, R.M. en J.G. March (1992/1963), A behavioral theory of the firm, Cambridge Mass.: Blackwell.

- Dahrendorf, R. (2002), Die Krisen der Demokratie: Ein Gespräch met Antonio Polito, Translated by R. Seuss, München: Verlag C.H. Beck.

Davenport, T.H. (2006), Competing on analytics, Harvard Business Review, vol. 84, no. 1 (January), pp. 98-107.

- De Kuijper, M. (2009), Profit power economics: a new competitive strategy for creating sustainable wealth, Oxford; New York: Oxford University Press.

- Dolan, S.L. en S. García Sánchez (2000), Managing by values in the next milenium: Cultural redesign for strategic organizational change, Avialable at SSRN: http://ssrn.com/ abstract $=237628$
- Donaldson, G. (1994), Corporate restructuring: Managing the change process from within, Boston, Mass.: Harvard Business School Press. - Doz, Y.L. (2005), Resource allocation processes in multidemensional organizations, MNCs and alliances, in: J.L. Bower en C.G. Gilbert (eds.), From resource allocation to strategy, (pp. 365-439), Oxford: Oxford University Press.

- Drucker, P.F. (1946), Concept of the corporation, New York: John Day.

- Drucker, P.F. (1958), Business objectives and survival needs: Notes on a discipline of business enterprise, The Journal of Business, vol. 31 ,

pp. 81-90.

Drucker, P.F. (1988), The coming of the new organization, Harvard Business Review, vol. 66, no. 1, (January/February), pp. 45-53.

- Fayol, H. (1918/1999), Administration industrielle et générale, Paris: Dunod.

- Fligstein, N. (1990), The transformation of corporate control, Cambridge, Mass: Harvard University Press

- Gallarza, M.G. en I.G. Saura (2006), Value dimensions, perceived value, satisfaction and loyalty: an investigation of university students' travel behaviour, Tourism Management, vol. 27, pp. 437-452.

- Garfinkel, H. (2008), Toward a sociological theory of information, Boulder, Colo.: Paradigm Publishers.

- Goold, M. en A. Campbell (1987), Strategies and styles: The role of the centre in managing diversified corporations, Oxford: Basil Blackwell. - Hammond, T.H. (1994), Structure, strategy, and the agenda of the firm, in: R.P. Rumelt, D.E. Schendel en D.J. Teece (eds.), Fundamental issues in strategy: A research agenda, Boston, MA: Harvard Business School Press.

- Hart, O. (1995), Firms, contracts, and financial structure, Oxford: Clarendon Press. - Hayek, F. (1945), The use of knowledge in society, American Economic Review, vol. 35, pp. 519-30

- Himanen, P. (2001), The hacker ethic, and the spirit of the information age, New York:

Random House.

- Jensen, M.C. (1993), Modern industrial revolution, exit, and the failure of internal control systems, Available at SSRN: http://ssrn.com/ abstract $=93988$. 
- Jensen, M.C. en W.H. Meckling (1999), Coordination, control and the management of organizations: Course notes, Harvard Business School, Available at: http://www.bmibourse. org/Report\%5CFiles\%5CSSRN-id78008.pdf

- Jorgenson, D.W. (2001), Information technology and the U.S. economy, The American Economic Review, vol. 91, pp. 1-32.

- Juran, J.M. (1995), Managerial breakthrough, New York: McGraw-Hill.

- Kaplan, R.S. en A.A. Atkinson (1989), Advanced management accounting, Englewood Cliffs, NJ: Prentice-Hall.

- Kaplan, R.S. en D.P. Norton (1996), The balanced scorecard: Translating strategy into action, Boston, Mass.: Harvard Business School Press.

- Kaplan, R.S. en D.P. Norton (2004), Strategy maps: Converting intangible assets into tangible outcomes, Boston, Mass: Harvard Business School Press.

- Kaplan, R.S. en D.P. Norton (2008), The execution premium: Linking strategy to operations for competitive advantage, Boston, Mass.: Harvard Business Press.

- Kim, W.C. en R. Mauborgne (2005), Blue Ocean Strategy: How to create uncontested market space and make the competition irrelevant, Boston, Mass.: Harvard Business School Press.

- Kocks, H.C. (2003), De relevantie van BIV voor accountant en controller, Maandblad voor Accountancy en Bedrijfseconomie, vol. 77, no. 5 pp. 225-235.

- Lash, S. (2002), Critique of information, London ; Thousand Oaks, Calif:: Sage.

- Lash, S. en J. Urry (1994), Economies of signs and space, London; Thousand Oaks, Calif.: Sage.

- Luhmann, N. (1968), Vertrauen: Ein

Mechanismus der Reduktion sozialer

Kompexität, Stuttgart: Lucius \& Lucius.

- Luhmann, N. (1984), Soziale Systeme:

Grundriß einer allgemeinen Theorie, Frankfurt

am Main: Suhrkamp.

- Malhotra, D.K. en M.H. Bazerman (2005),

Economics wins, psychology loses, and society pays, Available at: SSRN: http://ssrn.com/ abstract $=683200$

- March, J.G. (2006), Rationality, foolishness, and adaptive intelligence, Strategic Management Journal, vol. 27, no. 3, pp. 201-214.

- Marschak, J. en R. Radner, (1972), Economic theory of teams, New Haven: Yale University Press.
Merchant, K.A. en W.A. Van der Stede (2003), Management control systems: Performance measurement, evaluation and incentives, London: Prentice Hall.

- Nelson, R.R. en S.G. Winter (1982), An evolutionary theory of economic change, Cambridge, Mass.: Harvard University Press. - Osterwalder, A. (2004), The business model ontology: A proposition in a design science approach, l'Ecole des Hautes Etudes Commerciales, Université de Lausanne, Lausanne. - Peursen, C.A. van, C.P. Bertels en D. Nauta (1968), Informatie - Een interdisciplinaire studie, Utrecht: Aula-boeken.

- Pfeffer, J. en G.R. Salancik (2003), The external control of organizations: a resource dependence perspective, Stanford, Calif.: Stanford Business Books.

- Pfeffer, J. en R.I. Sutton (2006), Hard facts, dangerous half-truths, and total nonsense: Profiting from evidence-based management, Boston, MA: Harvard Business School Press.

- Picot, A., H. Dietl en E. Franck (2005), Organisation: Eine ökonomische Perspektive, Stuttgart: Schäffer-Poeschel Verlag.

- Prahalad, C.K. en M. S. Krishnan (2008), The new age of innovation: driving cocreated value through global networks, New York: McGraw-Hill. - Prahalad, C.K. en R.A. Bettis (1996), Dominant logic, in: M. Goold and K. S. Luchs (eds.), Managing the multibusiness company (pp. 398-420),. London: Routledge.

- Shannon, C. (1948), A mathematical theory of communication, Bell System Technical Journal, vol. 27 (July and October), pp. 379-423 en 623-656. - Simon, H.A. (1945/1976), Administrative behavior: A study of decision-making processes in administrative organization, New York: The Free Press.

- Simon, H.A. (1964), On the concept of organizational goal, Administrative Science Quarterly, vol. 9, no. 1, pp. 1-22.

- Simon, H. (1987), Making management decisions: The role of intuition and emotion, The Academy of Management Executive, vol. 1, pp. 55-64.

- Simon, H. (1991), Organizations and markets, Journal of Economic Perspectives, vol. 5, pp. 25-44.

- Simons, R. (1995), Levers of control: How managers use innovative control systems to drive strategic renewal, Boston, Mass.: Harvard Business School Press.
- Simons, R. (2005), Levers of organization design: How managers use accountability systems for greater performance and commitment, Boston, Mass.: Harvard Business School Press.

- Sloan, A.P. (1962/1986), My years with General Motors, Hammondsworth: Penguin Books. - Squire, J.E. (2004), The movie business book, New York: Fireside.

- Stinchcombe, A.L. (1990), Information and organizations, Berkeley: University of California Press.

- Strikwerda, J. (2002), Wat is ondernemingsbestuur? Maandblad voor Accountancy en Bedrijfseconomie, vol.76, no. 1/2, pp. 54-64.

- Strikwerda, J. (2008), Van unitmanagement naar multidimensionale organisaties, Assen Den Haag: Van Gorcum - Stichting Management Studies.

- Strikwerda, J. (2009), Terug van weggeweest: de Strategy Audit, Holland Management Review, no. 125, pp. 23-31. - Strikwerda, J. en J.W. Stoelhorst (2009), The emergence and evolution of the multidimensional organization, California Management Review, vol. 51, pp. 11-31. Sull, D.N. (2005), No exit: The failure of bottom-up strategic processes and the role of top-down disinvestment, in: : J.L. Bower en C.G. Gilbert (eds.), From resource allocation to strategy, (pp. 135-175), Oxford: Oxford University Press.

- Sutcliffe, K.M. en K. Weber (2003), The high cost of accurate knowledge, Harvard Business Review, vol. 81, no. 5 (May), pp. 74-82.

- Tricker, R.I. (1994), International corporate governance, New York: Prentice Hall.

- Wall, F. (2006), Informationsmanagement Eine ökonomische Integration von Controlling und Wirtschaftsinformatik, München: Verlag Franz Vahlen

Whitney, J.O. (1996), The economics of trust: Liberating profits \& restoring corporate vitality, New York: McGraw-Hill.

- Williamson, D.. (2007), The COSO ERM framework: a critique from systems theory of management control, International Journal of Risk Assessment and Management, vol. 7, pp. 1089-1119.

Wruck, K.H. en M.C. Jensen (1994), Science, specific knowledge and total quality management, Available at SSRN: http://ssrn. com/abstract $=55993$. 